2017-11-13

Library and Information Technology

Association (LITA)

Vacek, Rachel

https://hdl.handle.net/2027.42/146755

http://creativecommons.org/licenses/by-nc-nd/4.0/

Downloaded from Deep Blue, University of Michigan's institutional repository 


\title{
Library and Information Technology Association (LITA)
}

\author{
Rachel E. Vacek \\ University of Michigan, Ann Arbor, Michigan, U.S.A.
}

\begin{abstract}
The Library and Information Technology Association (LITA) is a division of the American Library Association (ALA), established in 1966. Through publishing, programs, training, national conferences, and strategic partnerships, LITA educates, serves, and reaches out to its members, ALA members and divisions, and the entire library and information technology community through the promotion and implementation of library automation and technology.
\end{abstract}

\section{INTRODUCTION}

The Library and Information Technology Association (LITA) is a division of the American Library Association (ALA). The division began in 1966 as the Information Science and Automation Division (ISAD) and became LITA in 1972. LITA's mission statement, adopted in May 1999, begins with its strategic mission "to educate, serve, and reach out" to the library community through the use and promotion of information technology. LITA celebrated its fiftieth anniversary in 2016.

\section{LITA VISION}

As the center of expertise about information technology, LITA leads in exploring and enabling new technologies to empower libraries. LITA members use the promise of technology to deliver dynamic library collections and services.

\section{LITA MISSION}

LITA educates, serves, and reaches out to its members, other ALA members and divisions, and the entire library and information community through its publications, programs, and other activities designed to promote, develop, and aid in the implementation of library and information technology.

\section{FUNCTION STATEMENT}

LITA is concerned with the planning, development, design, application, and integration of technologies within the library and information environment, with the impact of emerging technologies on library service, and with the effect of automated technologies on people. Its major focus is on interdisciplinary issues and emerging technologies. LITA disseminates information, provides educational opportunities for learning about information technologies and forums for the discussion of common concerns, monitors new technologies with potential applications in information science, encourages and fosters research, promotes the development of technical standards, and examines the effects of library systems and networks.

\section{MEMBERSHIP}

LITA membership (Table 1), like any organization, has increased and decreased over the course of its existence. Although LITA was established in 1966, members were not able to join until 1967. Initial membership started at 2334 people, and LITA membership peaked in 1993 with 5802 members. LITA's membership, like all the other ALA divisions, has been in decline since the early 2000s.

\section{GOVERNING STRUCTURE}

LITA is governed by a Board of Directors headed by the president (Table 2). In addition to the president, the Board includes the vice-president/president-elect, the immediate past president, the LITA/ALA councilor (representative of LITA on ALA's governing council), and seven directors at large. Ex officio members include the executive director (Table 3) of the division, the chair of the Bylaws and Organization Committee, and the chair of the Financial Advisory Committee.

The Executive Committee of the board is composed of the president, the vice-president, the past president, the LITA/ALA councilor, and one director chosen by the board each year, with the executive director being an ex officio member. The Board of Directors meets virtually and at every ALA Annual and Midwinter Conference, as 
Table 1 Information Science and Automation Division/ Library and Information Technology Association membership

\begin{tabular}{lc}
\hline Date & Total membership \\
\hline 2014 & 2,900 \\
2013 & 3,116 \\
2012 & 3,258 \\
2011 & 3,444 \\
2010 & 3,412 \\
2009 & 3,587 \\
2008 & 3,916 \\
2007 & 4,338 \\
2006 & 4,106 \\
2005 & 4,054 \\
2004 & 4,414 \\
2003 & 4,611 \\
2002 & 4,735 \\
2001 & 4,910 \\
2000 & 4,757 \\
\hline
\end{tabular}

does the Executive Committee. In addition, the Executive Committee meets virtually every spring and in-person in the fall near the ALA headquarters in Chicago, IL. The functions of LITA are carried out by approximately 50 committees and interest groups, most of which conduct business and hold meetings virtually, as well as at every ALA Conference.

\section{HISTORY}

\section{Early Years}

LITA's history, through approximately 1973, was delineated in the first edition of the Encyclopedia of Library and Information Sciences; the entry was entitled "Information Science and Automation Division (ISAD)." Going back to its earliest incarnation as the autonomous and unaffiliated "Coalition on Library Automation (COLA)" in the early 1960s, the group that would lay the foundation for today's LITA grappled with an issue that is still with the division today, that is, interest in technology runs across existing ALA divisions and types of libraries. From its inception, LITA has maintained a balance of service to other divisions, the library technology, and vendor community, and the ALA membership as a whole. To that end, LITA has consistently worked to develop and maintain a flexible, adaptable structure that focuses on facilitating education and information exchange to help those interested in the use of computer technology in library and informationrelated organizations to better perform their work.

In the same year as the retirement of ISAD's first executive secretary, 1973, then division president Ralph Shoffner appointed an Objectives Committee chaired by Stephen Salmon, ISAD's first president, to determine whether the division should continue. Concluding that the division's functions warranted continuation, new
Table 2 Information Science and Automation Division/ Library and Information Technology Association presidents

\begin{tabular}{|c|c|}
\hline Date & Name \\
\hline 1966-1967 & Stephen R. Salmon \\
\hline 1967-1968 & Joseph Becker \\
\hline 1968-1969 & Russell Shank \\
\hline 1969-1970 & Robert M. Hayes \\
\hline 1970-1971 & Richard DeGennaro \\
\hline 1971-1972 & Jesse H. Shera \\
\hline 1972-1973 & Ralph M. Shoffner \\
\hline 1973-1975 & Frederick G. Kilgour \\
\hline 1975-1976 & Henriette B. Avram \\
\hline 1976-1977 & Joseph A. Rosenthal \\
\hline 1977-1978 & Maurice J. Freedman \\
\hline 1978-1979 & Susan K. Martin \\
\hline 1979-1980 & Barbara E. Markuson \\
\hline $1980-1981$ & S. Michael Malinconico \\
\hline 1981-1982 & Brigitte L. Kenney \\
\hline 1982-1983 & Carolyn M. Gray \\
\hline 1983-1984 & Kenneth Dowlin \\
\hline 1984-1985 & Nancy L. Eaton \\
\hline 1985-1986 & Lois M. Kershner \\
\hline 1986-1987 & Raymond DeBuse \\
\hline 1987-1988 & William Gray Potter \\
\hline 1988-1989 & Sherrie Schmidt \\
\hline 1989-1990 & Carol A. Parkhurst \\
\hline 1990-1991 & Jo-Ann Michalak \\
\hline 1991-1992 & Paul Evan Peters \\
\hline 1992-1993 & Walt Crawford \\
\hline 1993-1994 & Tamara J. Miller \\
\hline 1994-1995 & Nancy K. Roderer \\
\hline 1995-1996 & Michele Dalehite (née Newberry) \\
\hline 1996-1997 & Thomas W. Leonhardt \\
\hline 1997-1998 & Linda D. Miller \\
\hline 1998-1999 & Barbra B. Higginbotham \\
\hline 1999-2000 & Michael J. Gorman \\
\hline 2000-2001 & Sara L. Randall \\
\hline 2001-2002 & Florence J. Wilson \\
\hline 2002-2003 & Pat Ensor \\
\hline 2003-2004 & Thomas Wilson \\
\hline 2004-2005 & Colby Riggs \\
\hline 2005-2006 & Patrick Mullin \\
\hline 2006-2007 & Bonnie Postlethwaite \\
\hline 2007-2008 & Mark Beatty \\
\hline 2008-2009 & Andrew K. Pace \\
\hline 2009-2010 & Michelle Frisque \\
\hline 2010-2011 & Karen Starr \\
\hline 2011-2012 & Colleen Cudy \\
\hline 2012-2013 & Zoe Stewart-Marshall \\
\hline 2013-2014 & Cindi Trainor Blyberg \\
\hline 2014-2015 & Rachel E. Vacek \\
\hline 2015-2016 & Thomas Dowling \\
\hline 2016-2017 & Aimee Fifarek \\
\hline 2017-2018 & Andromeda Yelton \\
\hline 2018-2019 & Bohyun Kim \\
\hline
\end{tabular}

objectives were created that highlighted ISAD's programs, advisory services, publications, discussion groups, and standards promotion; the group's objectives were then revised accordingly. 
Table 3 Information Science and Automation Division/ Library and Information Technology Association executive directors

\begin{tabular}{ll}
\hline Date & \multicolumn{1}{c}{ Name } \\
\hline $1967-1973$ & Don S. Culbertson \\
$1973-1986$ & Donald P. Hammer \\
$1987-1995$ & Linda J. Knutson \\
1996 & Lillian Lewis (acting) \\
$1996-2001$ & Jacqueline Mundell \\
$2001-2015$ & Mary Taylor \\
$2015-$ & Jenny Levine \\
\hline
\end{tabular}

Following the restatement of purpose, and with the approval of the membership, ISAD changed its name to the Library and Information Technology Association. Various early division periodical publications were subsumed in 1973 into the referred Journal of Library Automation (JOLA). In 1982, the journal's editors selected a new name more reflective of the name change of the division and JOLA became Information Technology and Libraries (ITAL; Table 4). A LITA Newsletter was published from 1979 to 2000. Issues from Spring 1995 to Summer 2000 were published electronically, with issues from Winter 1997 to Summer 2000 being available only in electronic format. An abbreviated supplement, LITA Notes, was published as part of ITAL from 1997 through March 2000. The LITA Newsletter editors included Pat Barkalow, Carol Parkhurst, Walt Crawford, Gail Junion-Metz, and Martin Kalfatovic. Since 2000, the LITA news function has been subsumed by the divisional website and blog, as well as periodic electronic mailings to the membership.

With the goal of greater member participation in the division, and with objectives and a name change firmly in place, LITA underwent a major reorganization in 19841985. Many of the committees were restructured, and LITA went back to its COLA discussion group roots to encourage the creation of varied interest groups. Ten or more LITA members could petition to form an interest group in a library/information technology topic; if the

Table 4 Journal of Library Automation/Information Technology and Libraries editors

\begin{tabular}{ll}
\hline Date & \multicolumn{1}{c}{ Name } \\
\hline $1968-1971$ & Frederick G. Kilgour \\
1972 & A.J. Goldwyn \\
$1973-1977,1980$ & Susan K. Martin \\
$1978-1979$ & William D. Mathews \\
$1981-1983$ & Brian Aveney \\
$1984-1989$ & William Gray Potter \\
$1990-1995$ & Thomas W. Leonhardt \\
$1996-1998$ & James J. Kopp \\
$1999-2004$ & Dan K. Marmion \\
$2004-2007$ & John Webb \\
$2007-2011$ & Marc Truitt \\
$2011-2017$ & Robert Gerrity \\
\hline
\end{tabular}

interest group's formation was approved-and the vast majority are to this day-by the LITA Board, the group can elect officers, organize discussions, put on programs, create publications, and perform other educational and information exchange functions. New interest groups are formed and disbanded on a regular basis; at any given time, 15-20 interest groups are active in the division. This model reflects the ever-changing landscape in information technology.

Another major initiative that began in the late 1970s/ early 1980s is the provision of sponsored awards and scholarships that support achievement and study in library and information technology. Stemming from this time period are the LITA/Gaylord Award for Achievement in Library and Information Technology, LITA participation in the multidivisional Hugh C. Atkinson Memorial Award, and the LITA/Computer Library Services, Inc. (later the LITA/GEAC) scholarship to encourage entry into the library automation field.

High demand for workshops and face-to-face discussions also led to the creation of National Conferences in the 1980s and 1990s. These large-scale multipleday gatherings involved presentation of papers, vendor exhibits, workshops, and computer demonstrations. The national conferences in Baltimore (1983), Boston (1988), and Denver (1992) were well attended and financially successful.

\section{The Internet Era}

Trends within the LITA division can be tracked along with those throughout the other divisions, libraries, and even the world at large. These trends and influences include the decline of the spending power of libraries, an increasingly rapid pace of change in technology, the growing attention to empowering diverse population groups, the advent and spectacular growth of the Internet as a worldwide network, the rapid improvements in computing power, and a resulting exponential increase in the amount of available electronic content.

As it became clear that no area of libraries-and no type of library - would be untouched by information technology, and, therefore, that most library organizations became concerned by technology topics, LITA shifted its focus and identity to leadership in the more advanced use of technology in libraries and other related organizations. The 1990s also cemented the role of systems librariansdegreed professionals with added expertise in hardware, software, networks, and computing-establishing LITA as the logical division for these professionals' participation. LITA also emerged as a home for a growing number of information science and IT professionals who are not librarians.

In 1996, the supposed last LITA National Conference was cosponsored by the Library Administration and Management Association division and held in Pittsburgh, 
Table 5 LITA National conference/national forum venues

\begin{tabular}{ll}
\hline LITA National conference/national forum \\
\hline Date & \multicolumn{1}{c}{ Place } \\
\hline 1983 & Baltimore, Maryland \\
1988 & Boston, Massachusetts \\
1992 & Denver, Colorado \\
1996 & Pittsburgh, Pennsylvania \\
1998 & Oakland, California \\
1999 & Raleigh, North Carolina \\
2000 & Portland, Oregon \\
2001 & Milwaukee, Wisconsin \\
2002 & Houston, Texas \\
2003 & Norfolk, Virginia \\
2004 & St. Louis, Missouri \\
2005 & San Jose, California \\
2006 & Nashville, Tennessee \\
2007 & Denver, Colorado \\
2008 & Cincinnati, Ohio \\
2009 & Salt Lake City, Utah \\
2010 & Atlanta, Georgia \\
2011 & Columbus, Ohio \\
2012 & Louisville, Kentucky \\
2013 & St. Louis, Missouri \\
2014 & Albuquerque, New Mexico \\
2015 & Minneapolis, Minnesota \\
2016 & Fort Worth, Texas \\
2017 & Denver, Colorado \\
\hline &
\end{tabular}

Pennsylvania. Despite good attendance and feedback from participants, the expenses and the 3-yr planning cycle of the endeavor led LITA to determine that this was not the best method for continuing its own major conference. In 1998, LITA had its first annual National Forum. Taking place in Oakland, California, the more focused format was an immediate success. Education opportunities, attendee satisfaction, divisional revenue, and the development of training opportunities through regional institutes and preconferences continue to make LITA Forum a popular annual event (Table 5).

LITA became an early supporter of the move to encourage diversity in the library profession by creating the LITA/OCLC and LITA/Library Systems and Services, Inc. minority scholarships in Library and Information Technology. Additional awards and scholarships created in the 1990s have included the LITA/Ex Libris Student Writing Award, the Frederick G. Kilgour Award for Research in Library and Information Technology (jointly sponsored by LITA and OCLC), and the LITA/Christian Larew Memorial Scholarship (sponsored by Baker \& Taylor). The LITA/Library Hi Tech Award (sponsored by LITA and Emerald Press) rewards innovation and scholarship in library technology. Awarded each year, these competitive awards not only engage the partnership of sponsors, but give a meaningful leg up to new professionals and reward those most active in library technology. The LITA/Brett Butler Entrepreneurship Award (sponsored by LITA and Gale) was retired in 2009.
LITA was also a pioneer among library associations in the area of electronic communications. An electronic edition of the LITA Newsletter was first published in 1995. The first electronic-only serial publication by a division of ALA, Telecommunication Electronic Reviews (TER), appeared in 1994 and spawned many imitators. In 2009, LITA retired TER in favor of community-based blog and wiki communication platforms. LITA garnered the thanks of ALA members at large by originating Internet rooms at ALA conferences, setting up and managing the Internet rooms at seven ALA Annual and Midwinter conferences from 1993 through 1996.

In 1996, the LITA website, http://www.lita.org, was created, as was the LITA electronic discussion list, LITAL. In 1998, LITA created an online jobs list-"Jobs in Library and Information Technology" that has been heavily used by job posters and job seekers since then.

\section{Twenty-First Century}

With the advent of weblogs, social software, and groupedited wiki sites, LITA established an online presence for open participation and discussion of library technology issues with its LITA Blog (litablog.org) in 2005 and LITA Wiki (wikis.ala.org/lita) in 2006. Many of the members instrumental in establishing a foothold with these technologies established the Blogs, Interactive Groupware Wikis Interest Group (BIGWIG). In 2008, BIGWIG launched Your BIGWIG (yourbigwig.com) and established itself as the leading social software discussion group within ALA. BIGWIG hosted the extremely well attended Social Software Showcase, an "unconference" that occurred both virtually and physically at every ALA Annual Conference. However, as more structure for social technology was needed within LITA, and as other divisions, roundtables, committees, and interest groups embraced social software, BIGWIG's purpose had been served, and in 2011, the interest group retired.

In 2009, ALA had also created a new tool called ALA Connect (connect.ala.org), which was intended to be the centralized space where both unofficial and official ALA groups are able to work together online. This content management system, built on the open-source Drupal platform, greatly impacted LITA. Having multiple web-based tools for different purposes can be helpful, but managing content and having working spaces across a blog, wiki, website, and within ALA Connect seemed to be a few too many places. It became unclear on each tool's purpose. It was decided in 2011 that the LITA Web Coordinating Committee would manage the Blog and Wiki. Then in 2012, the Wiki was retired and LITA members were encouraged to use ALA Connect as a workspace for all committee and interest group business.

ALA Connect has also served the LITA Board and Executive Committee as a place to organize and share meeting notes, vote on issues, and engage with the 
community in new ways. Posts can be marked as public or private, and users can add comments, attachments, create polls, make meeting time requests, or even chat, all within ALA Connect. It has significantly helped make more accessible the intuitional memory of LITA's digital presence.

During the mid-2000s, capturing and then immediately sharing the digital recordings of speakers, board meetings, and major events like the Top Technology Trends, the President's Program, or keynote speakers at the LITA Forum became extremely important to LITA. Travel to conferences was financially challenging for many people at this time due to library travel funds being reduced or cut completely. Consequently, the desire to participate virtually (such as watching a live stream while discussing the event through a Twitter backchannel) was increasing. Many of LITA's educational events were streamed live, or were recorded and made available at later times. Jason Griffey, LITA Board Member (2011-2014), was the primary source for audio and video equipment, provided the recording expertise and posted the digitized events for LITA for most of the past decade.

During the late 2000s, LITA's online presence continued to expand. LITA engaged and informed current and potential members on social media sites like YouTube, Twitter, and Facebook. Additionally, more educational opportunities were being created for virtual consumption. Perhaps the most significant online transition was that of LITA's peer-reviewed journal, Information Technology and Libraries (ITAL), which moved from a print format to a free journal with unrestricted online access. The transition to being an open-access journal took approximately 2 yrs, between 2010 and 2012. Embarking on an e-publishing model only has helped ensure the long-term viability of ITAL by making it more accessible, more current, more relevant, and more environmentally friendly. ITAL continues to feature high-quality articles that have undergone a rigorous peer-review process, but it also expanded content to include more case studies, commentary, and information about topics and trends of interest to the LITA community and beyond. Although many LITA members helped with the open-access transition, key people included Kristin Antelman, Bob Gerrity, Maurice York, and Michelle Frisque.

Over the past $15 \mathrm{yrs}$, almost all the divisions of ALA experienced financial challenges and saw a trend of flat or declining membership, and LITA was no exception. In 2012, the LITA Financial Strategies Task Force was established under President Zoe Stewart-Marshall (20122013) to reexamine existing financial strategies and revenue sources for the Division and identify strategies based upon a sustainable infrastructure to allow LITA to continue to provide valued networking and educational opportunities by and to its members. Their final report, full of short-term and long-term recommendations, was presented to the Board in early 2014. Later that year, under President Cindi Blyberg (2013-2014), the Financial Advisory Committee was established. Many of the recommendations will continue to be reviewed and implemented in years to come.

In addition to creation of the Financial Advisory Committee, other changes were made to LITA committees in the 2000s and early part of the decade. In 2008, the Assessment and Research Committee was formed to work with other LITA groups to assess progress against the strategic goals through the collection and assessment of data and feedback. This committee, like many others, originally started out as a task force that was charged to conduct research and present a final report to the Board with future recommendations.

In 2012, a Metadata Standards Committee was established that has appointed membership from LITA, the Association for Library Collections \& Technical Services, and the Reference \& User Services Association. In 2014, the Board voted to disband both the International Relations Committee and the Technology and Access Committee because much of the work of these committees was being done at the ALA level, and these committees had been created at a time when there was not as much focus on these topics in libraries.

Later in 2014, president Rachel Vacek saw the need to help LITA streamline, improve branding, and more effectively communicate across LITA's virtual presence and proposed to the Board a committee to help with these efforts. In October 2014, the Communications and Marketing Committee was created. To compliment these communication efforts, the Web Coordinating Committee also hired a blog manager, Brianna Marshall, who along with a dozen dedicated blog writers, have a goal to revitalize LITA's blog and social media presence. In a short few months, organic reach and engagement had explosive growth and positive feedback from members and nonmembers alike.

\section{STRATEGIC FUNCTIONS AND MAIN PROGRAMS}

In 1998-1999, under the presidency of Barbra Buckner Higginbotham and the leadership of president-elect and future ALA president Michael Gorman, LITA went through a process of reexamining its strategic directions, resulting in a sharpened and renewed focus on educating, serving, and reaching out. Many LITA activities fulfill more than one of these objectives that help LITA maintain its status for IT leadership within ALA in particular and libraries in general.

Under the initial leadership of president Colby Riggs (2004-2005), the LITA Board of Directors approved its first detailed strategic plan for the years 2005-2008. Establishing the Mission, Vision, and Function of the division, the plan set a tactical objective to fulfill its strategy to educate, serve, and reach out, established in the late 1990s. 
President Michelle Frisque (2009-2010) and the LITA Board led the creation of LITA's second ambitious strategic plan for the years 2008-2011 that focused on the organization, innovation, training and continuing education, collaboration and outreach, and advocacy and policy. Input was gathered through surveys, open forums, and the LITA Town Meetings at ALA Midwinter conferences. From 2013 to 2015, the work of the LITA Board focused on four goal statements from the previous Strategic Plan. The division's principal focus on education, publishing, and networking remained the same, but other ideas including collaboration, advocacy, and infrastructure were incorporated. These concepts have been central to the Board's and the membership's work over the past several years and reflect the LITA gestalt.

\section{EDUCATION}

In the area of education, LITA presents 15-20 programs at every ALA Annual Conference on a wide variety of technology-related topics, such data management, linked data, web analytics, search engine optimization, user experience, digital libraries, graphical information systems, and languages like Python or XML. Popular programs, such as Top Technology Trends, the Ultimate Debate, and the President's Program draw large crowds and are immensely popular. In addition, two preconferences are scheduled along with every Annual Conference, allowing more in-depth presentations of specific topics. Such daylong workshops are also sometimes presented as regional institutes, as previously noted, often in partnership with other associations and agencies. The annual LITA National Forum is perhaps the most popular educational venue.

However, despite all success of the in-person educational offerings, the advent of new technologies has also given LITA the opportunity to create new strategies for virtual education, unconstrained by time and place. These strategies have created numerous opportunities for members and nonmembers alike. Webinars and online courses taught over the course of multiple weeks and utilizing Adobe Connect, a web conferencing platform, have become increasingly popular and have become a great revenue-generating avenue for LITA to explore more and expand.

LITA's publications have long served as a source of excellent education in library and information technology. In addition to the open-access periodical, ITAL, almost since its inception, LITA has published monographic works of great value to the library and information technology community, and many LITA members are active in library science publishing. A drop-off in the production and profitability of monographic publishing has led LITA to focus on the publication of brief, practical, useful handbooks - LITA Guides - for the use of technology in libraries and related institutions. ITAL continues to attract serious scholarly additions to the field of library automation, digital libraries, systems, and web technology.

\section{SERVICE}

Of course, the efforts listed under the function of education can also be considered part of LITA's service objective. The LITA website has become the focus of LITA's provision of services to the library and information technology community. In addition to the previously mentioned online "Jobs in Library and Information Technology" site, LITA has drawn on the expertise of individual members and subgroups of LITA to provide information and recommendations on a variety of subjects.

In addition to the resources available on the main LITA website, the library and information technology community continually benefits from virtual activities of LITA members. Most conference activities are actively blogged and tweeted by participants, not only creating a record of the activity, but a forum in which those not in attendance can be updated and participate in topical discussions.

LITA has sponsored one or two LITA members almost every year to participate in ALA Emerging Leaders program. The Emerging Leaders program is designed to develop the next generation of library leaders from across the country to participate in problem-solving workgroups, network with peers, gain an inside look into ALA structure, and have an opportunity to serve the profession in a leadership capacity. By sponsoring ALA Emerging Leaders, LITA has an opportunity to help create new leaders while benefiting from the participation of that new leader in the work of the division. Projects are approved by the Board and have focused on service to LITA through creating documentation, workflows, orientation materials, and new programs, as well as providing recommendations on branding, collaborations, and web tools. These emerging leaders have been instrumental to moving forward new ideas and needed change within the organization, and continuing to support this valuable initiative has been a priority of the LITA Board since the programs' inception in 2007.

\section{OUTREACH}

LITA's outreach objective is aimed at "a broad membership, new professionals, systems librarians, library administrators, and vendors." Of course, many of the projects mentioned above are also efforts to reach out. In addition, LITA works closely with ALA's Office for Information Technology Policy and is a member of other related organizations, such as the Coalition for Networked Information and EDUCAUSE. 
LITA is also involved with the creation, promotion, and endorsement of newly developed standards and maintains a close working relationship with the National Information Standards Organization. New initiatives aimed at more technical audiences, such as Code4Lib, and administered by groups such as the Digital Library Federation also include the participation of many LITA members and volunteers.

\section{FUTURE DIRECTIONS}

LITA will continue other efforts to make use of electronic communication practices, social software use, and online education and publication to support organization activities. "Virtual membership" and participation on committees continue to increase, and many groups within LITA conduct business between meetings via virtual methods. LITA's web presence-website, blog, ALA Connect, and social media channels - will continue to be the home of new educational efforts and useful material for LITA members. LITA is also an eager partner with ALA in its efforts to improve virtual membership and participation, including online communities, e-commerce functions, and social networking. LITA will also continue to partner with ALA in finding solutions to technology challenges such as net neutrality, E-Rate, broadband, copyright, and open access to digital content.

Moving forward with the development of a new strategic direction under the leadership of president Thomas
Dowling (2015-2016), LITA will continue its theme of educating, serving, and advocating, even if the tactics in doing so change. Continued recruitment to the division of nonlibrarians, other divisional members, and professionals new to the field will be vital in moving forward. LITA is a division whose direction comes from its leaders and staff, but whose strength comes from its volunteer membership.

\section{BIBLIOGRAPHY}

1. Culbertson, D.S. Information Science and Automation Division (ISAD), ALA. In Encyclopedia of Library and Information Science; 1st Ed.; Kent, A., Lancour, H., Daily, J.E., Eds.; Marcel Dekker, Inc.: New York, 1968-1998; Vol. 11, 495-500.

2. Ensor, P. Library and information technology association. Encycloped. Libr. Inform. Sci. 2003, l (1), 1653-1656.

3. LITA Strategic Plan. 2005-2008, Library and Information Technology Association Strategic Plan for 2005-2008, http://www.lita.org/ala/lita/aboutlita/org/plan.cfm (accessed May 23, 2017).

4. LITA Strategic Plan. 2008-2011, LITA Strategic Plan: Goals \& Objectives, 2008-2011, http://www.ala.org/lita/ sites/ala.org.lita/files/content/about/strategic/2010-strategic.pdf (accessed May 23, 2017).

5. Pace, A.K. Library and information technology association. Encyclopedia of Library and Information Science 2009.

6. Salmon, S.R. LITA's first twenty-five years: A brief history. Inform. Technol. Libr. 1993, 12 (1), 15-35. 